\title{
Incidence and severity of major fungal diseases on tomato in three districts within the forest and forest-savannah agro- ecological zones of Ghana
}

\author{
B. A. OPOKU*, C. KWOSEH, E. GYASI \& E. MOSES \\ (B.A.O. \& C.K.: Department of Crops and Soil Science, KNUST, Kumasi, Ghana; E.G.: Plant \\ Pathology Section, CSIR-Plant Genetic Resources Research Institute, Bunso, Ghana; E.M.: \\ Plant Health Division, CSIR-Crops Research Institute, Fumesua, Kumasi, Ghana) \\ *Corresponding author's email: opokuasante30@yahoo.com/opoku09@live.com
}

\begin{abstract}
This study was initiated to determine the incidence and severity of fungal diseases of tomatoes and document farmers' knowledge of these diseases and their control measures in Offinso North, Techiman North and Asante Akim North Districts within the forest and forest-savannah agro-ecological zones of Ghana. A survey was conducted in three selected communities in each district to document the incidence and severity of fungal diseases of tomato and also farmers' knowledge of fungal diseases of tomato and control practices adopted on their farms using a well-structured questionnaire. Early blight, Septoria leaf spot, Fusarium wilt, Crown rot and Sclerotium rot were the major fungal diseases identified in the study. The mean incidence of diseases recorded for the districts was low with the exception of early blight with an incidence of $63.9 \%$ at Asante Akim North District. Though the mean fungal disease severities in the three districts were also low, the highest score was recorded by early blight and fusarium wilt in the Asante Akim North District and fusarium wilt and sclerotium rot in the Offinso North District. In general, farmers had perceived knowledge of the tomato diseases because of losses that these diseases caused, but their knowledge on control was poor.
\end{abstract}

Keywords: Fungal diseases; incidence; severity; survey; tomato Original scientific paper. Received 29 Apr 2020; revised 05 Aug 2021

\section{Introduction}

Tomato (Solanum lycopersicum L.), known to be a nightshade crop, belongs to the family of Solanacaeae and is consumed in diverse ways, including fresh, as an ingredient in many dishes, sauces and in drinks (Alam et al., 2007). Many Ghanaian dishes have tomatoes as an ingredient (Tambo \& Gbemu, 2010). Tomatoes are very rich in vitamins A, B and $\mathrm{C}$ and also contain good amount of potassium, iron, and phosphorus (Wener, 2000). In major tomato producing areas of Ghana, such as Akomadan, Tuobodom, Techiman and Agogo, tomato cultivation is a source of employment to about $80 \%$ of the populace (Sinnadurai, 1992). According to report from MoFA (2002), high yields of tomato result in high incomes to farmers, especially in areas of Akomadan, Tuobodom, Agogo, Mankessim and Navrongo where it is cultivated almost three to four times per year.

Ghana Jnl Agric. Sci. 56 (2), 46 - 60

GJAS is an Open Access Journal and distributed under the terms of the Creative Commons (CC) License [CC BY 4.0] 
In recent years, local production of tomatoes is not able to meet the domestic high demand hence tomatoes are often imported mainly from Burkina Faso (Ghanaweb.com, 2020; Asselt et al., 2018; Gonzalez et al., 2016; Horna et al., 2008; Horna et al., 2006). This situation is due to myriads of constraints, particularly diseases and pests (Coolong \& Boyhan, 2017; Kari et al., 2017; Duodu, 2014; Villareal, 1980). Several pathogens that infect tomatoes have been reported worldwide. Among the economically important pathogens are fungi, nematodes, viruses and bacteria (Jones et al., 1991; Chupp \& Sherf, 1960). Fungal diseases of tomato such as early blight, late blight, Septoria leaf spot, Fusarium wilt, Crown rot, Collar rot, Sclerotium rot and damping-off have been reported in Ghana and different parts of the world (Offei et al., 2008; Shankara et al., 2005; Agrios, 2005; MoFA, 1995; Clerk, 1974). In Ghana, such fungal diseases affect crop growth, reduce yields and critically affect farmers' income and livelihoods (GSSP Report, 2010; IFPRI-PBS, 2006). Quantitative information on the incidence and severity of tomato fungal diseases and the level of monetary losses these fungal diseases cause in tomato cultivation cannot be overlooked in Ghana. Observations, however, on farmers' fields show that severe disease pressure has led to farmers' abuse and overdependence on chemicals to control diseases. To help develop appropriate fungal disease control measures, a better understanding of the disease situation in major tomato growing areas of Ghana must be known. The study is an attempt to document the actual field diseases situation of tomatoes with the aim that results obtained can be depended on to develop appropriate control measures. The objectives of the study were to determine the incidence and severity of major fungal diseases of tomatoes and document farmers' knowledge of these diseases and their control measures in three districts within the forest and forest-savannah agro-ecological zones of Ghana.

\section{Materials and Methods}

Documentation of incidence and severity of fungal diseases of tomatoes

A survey was conducted in some selected communities in the following major tomato growing districts; Offinso North District (Nkenkaasu, Akomadan, Afrancho) (Fig. 1), Techiman North District (Tuobodom, Tanoboase and Ofuman) (Fig. 2) and Asante Akim North District (Agogo township, Nyinatokro and Abrewapon) (Fig. 3) to document incidence and severity of fungal diseases of tomatoes from August to November, 2011. 


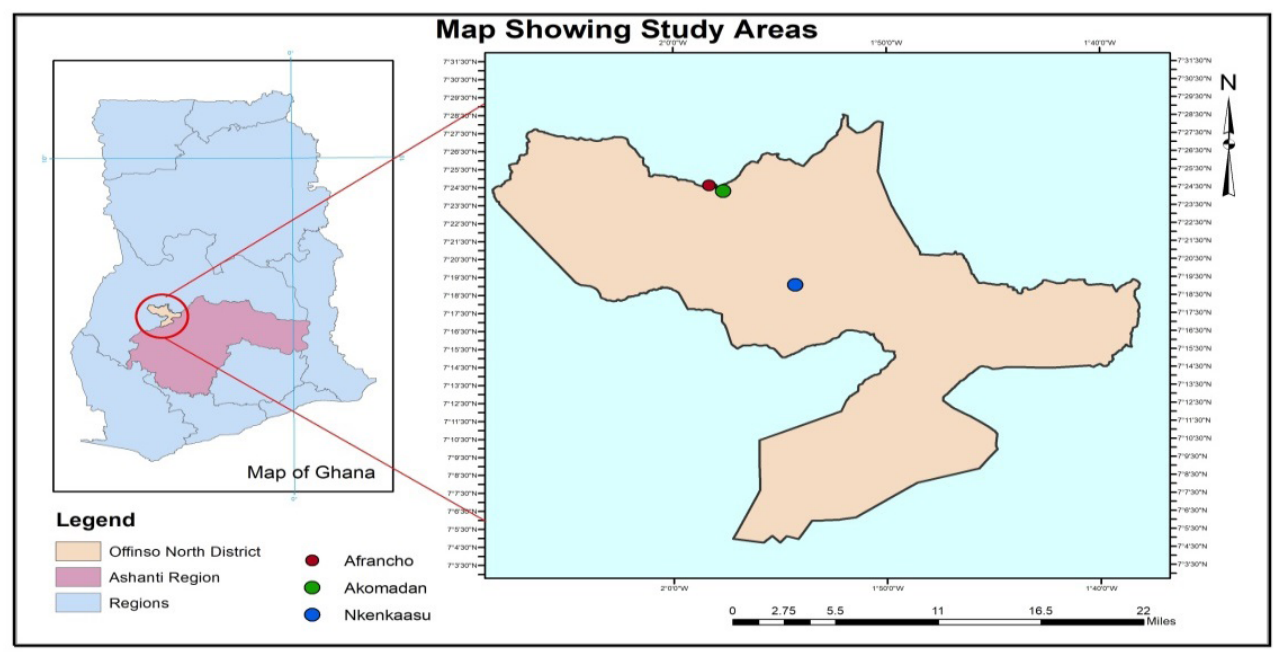

Fig. 1: Map of Offinso North District showing the communities' questionnaires were administered

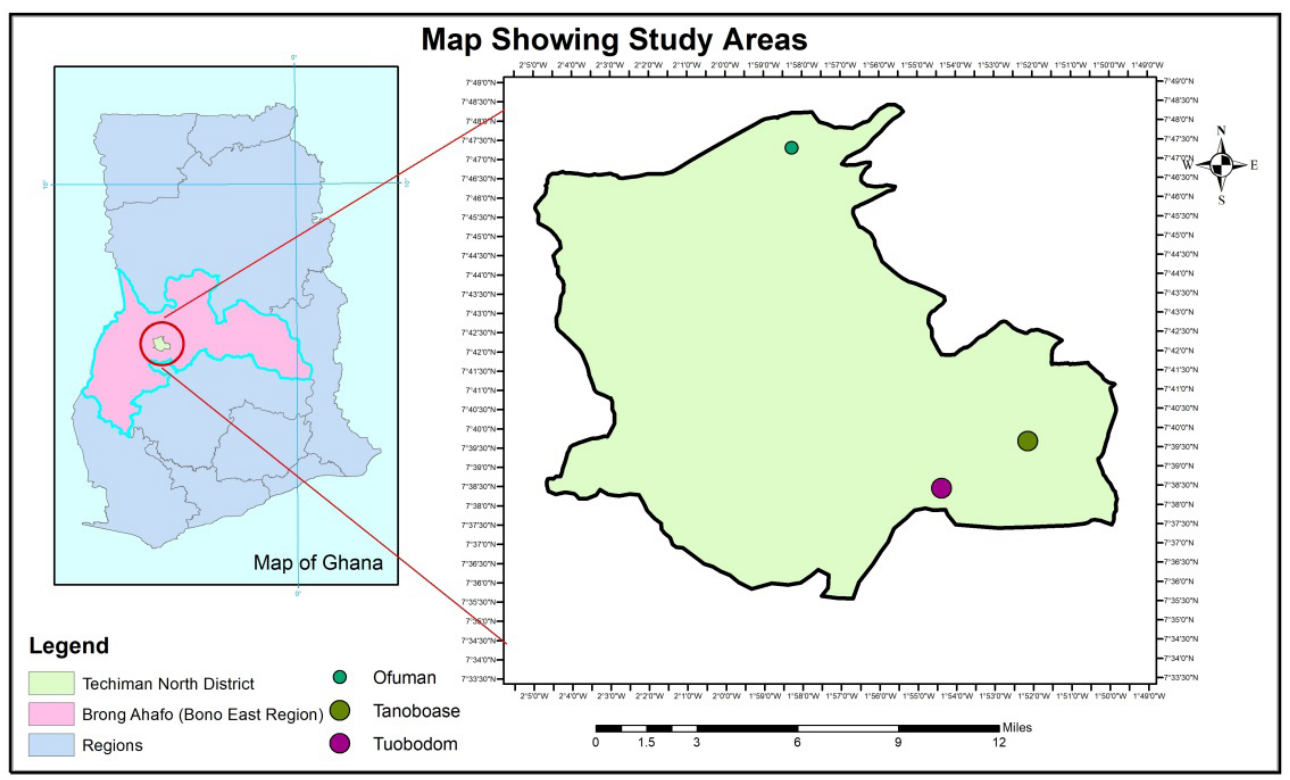

Fig. 2: Map of Techiman North District showing the communities' questionnaires were administered 


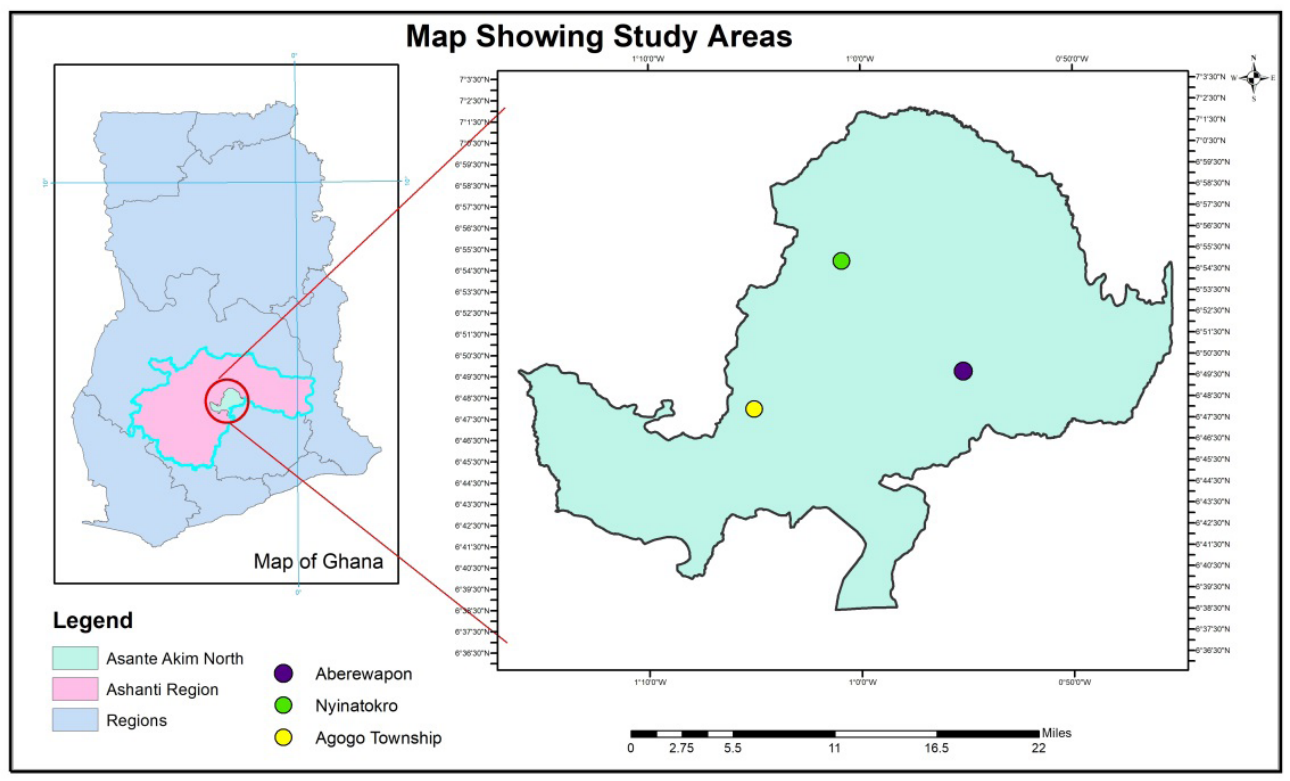

Fig. 3: Map of Asante Akyem North District showing the communities' questionnaires were administered

Survey of tomato farms was conducted at the flowering stage in all the districts. The distance between the selected farms in a community was $0.5-1 \mathrm{~km}$ apart. In each district, 30 farms were randomly selected and screened. On each farm, 30 tomato plants were randomly selected in a diagonal direction across the farm and were examined for incidence and severity. The tomato farms selected for scoring were $0.40-0.80$ ha in size. Petomech (locally called by the farmers as Peto or Petofake), Power-Rano ("Abonkruwa" or Rano), Power (locally called by the farmers as "Caterpillar" ( Power Rasta") and "Akoma" were the tomato cultivars identified in the studied communities but Power-Rano was the dominant cultivar cultivated by the farmers.
A modified disease severity scale by CSIRCrops Research Institute (2011) was used to score the diseases as follows:

$1 \rightarrow$ No disease symptoms expression on tomato plant

$2 \rightarrow$ Disease symptoms expression on leaf of tomato plant to cover $5-25 \%$ of the total leaf (ves) area

$3 \rightarrow$ Disease symptoms to cover $25-50 \%$ of the total leaf (ves) area

$4 \rightarrow$ Disease symptoms to cover $50-75 \%$ of the total leaf (ves) area of tomato plant

$5 \rightarrow$ Disease symptom expression on leaf and tissues to cover $75-100 \%$ of the total leaf (ves) area causing complete death of tomato plant to 
the point of no recovery or no yield attained. Final disease incidence and severity were calculated using the formula recommended by CSIR- Crops Research Institute (2014) as below:

$$
\begin{aligned}
& \text { Disease incidence }=\frac{\text { Number of infected plants }}{\text { Total plants scored }} \times 100 \% \text { and } \\
& \text { Disease severity }=\frac{\left.\sum \text { (Number of plants scored for each rating } \times \text { the rating value }\right)}{\text { Total plants scored per farm }}
\end{aligned}
$$

The data collected were fungal disease incidence per farm/district and fungal disease severity per farm/district. Samples of all tomato plants scored for fungal disease incidence and severity on the farms in the districts were collected and put into ziplock bags. The samples were well labelled and transported in an ice chest to the Plant Pathology Laboratory of CSIR-Crops Research Institute (CSIR-CRI) for confirmation of the diseases identified on the field.

Documentation of farmers' knowledge on fungal diseases affecting tomato and control practices

90 tomato farmers whose farms were surveyed for incidence and severity of fungal diseases affecting tomatoes in the three districts were individually interviewed using a well-structured questionnaire. Data on their awareness of fungal diseases and control practices were documented. The data collected include;

i. farmers' knowledge and perceptions on the identified fungal diseases of tomato,

ii. farmers' control measures to the identified tomato fungal diseases,

iii. farmers' source of seedlings and

iv. cost of tomato production and yield per 0.40 ha with disease and no disease effect, (data on yield and cost of tomato production were with respect to 0.40 ha as presented by the farmers because the land sizes of most of the farms surveyed were $0.40 \mathrm{ha}$ ).
Preparation of potato dextrose agar (PDA) for isolation of fungi

$200 \mathrm{~g}$ of peeled potato, $20 \mathrm{~g}$ of glucose, $20 \mathrm{~g}$ of agar and one litre of distilled water were used to prepare one litre PDA. The peeled potato tubers were cut into pieces with a sterilised knife, weighed, washed and boiled in $500 \mathrm{ml}$ of distilled water. The potato was then mashed in the boiling water and sieved three times through a cheesecloth to obtain the potato extract. Then $20 \mathrm{~g}$ of glucose was added to the potato extract and stirred thoroughly, using a magnetic stirrer (Stuart Scientific, UK). The agar (20 g) was melted in the potato-glucose mixture in a beaker and was topped with distilled water to a litre full. The PDA was sterilised in an autoclave at $121^{\circ} \mathrm{C}$ for 20 minutes. It was allowed to cool to about $45^{\circ} \mathrm{C}$ and amended with $500 \mathrm{mg}$ chloramphenicol (antibiotic) before dispensing into sterilised Petri dishes.

\section{Isolation and identification of fungal}

pathogens from diseased tomato plants

Isolation of fungal pathogens from diseased tomato plants was done at the Plant Pathology Laboratories of Faculty of Agriculture, KNUST andCSIR-Crops Research Institute(CSIR-CRI), Kumasi, to identify and confirm the causative organisms of the infections encountered on farmers' field during the survey. Small pieces of the leaf and stem tissues of infected tomato plants were removed with a sterilised knife and surface sterilised in $1 \%$ bleach for one minute. 
The pieces of diseased plant tissues were then rinsed three times in sterilised distilled water and allowed to dry in a laminar flow cabinet for 20 minutes. The pieces were plated on PDA in $90 \mathrm{~mm}$ diameter sterilised Petri dishes and incubated at $28^{\circ} \mathrm{C}$ for seven days in an incubation room. The developing fungal colonies were sub-cultured on fresh PDA plates and pure cultures of microbial growth were established for identification. The fungal isolates were identified based on their cultural and morphological characteristics including shapes of spores or conidia, mycelial colour amongst others. The fungal identification was carried out using a compound microscope (Hund Wetzlar, H-500, Germany) with the aid of fungi descriptive manuals developed by Mathur and Kongsdal (2003) and Barnett and Hunter (1972).

\section{Presentation of Data}

Calculations were done on data for each disease incidence and severity. They were summarized for their mean percentages per district and the results were presented in Tables. Response of the questionnaire on farmers' knowledge of diseases on their tomato farms and their control practices, as well as farmers' sources of seedlings were summarized in percentages and presented in bar charts using Microsoft Excel. Fungal species identified from the diseased tomato plants were also recorded. Data on the cost and yield of tomato production obtained from the farmers per 0.40 ha land size was also presented in a Table.

\section{Results}

Major fungal diseases of tomato identified in the studied districts

A total of five fungal diseases were identified on sampled tomato plants in the study areas. The diseases were Early blight (Fig. 4), Fusarium wilt (Fig. 5), Crown rot (Fig 6), Sclerotium rot (Fig. 7) and Septoria leaf spot (Fig. 8). The symptom expressions of these diseases were scored from farmers' fields.

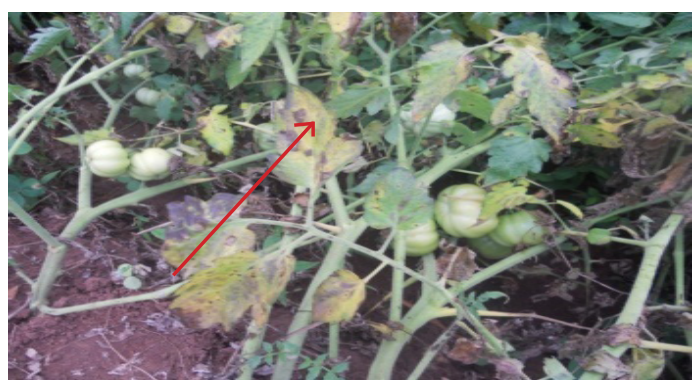

Fig. 4: Early blight of tomato (Symptoms arrowed)

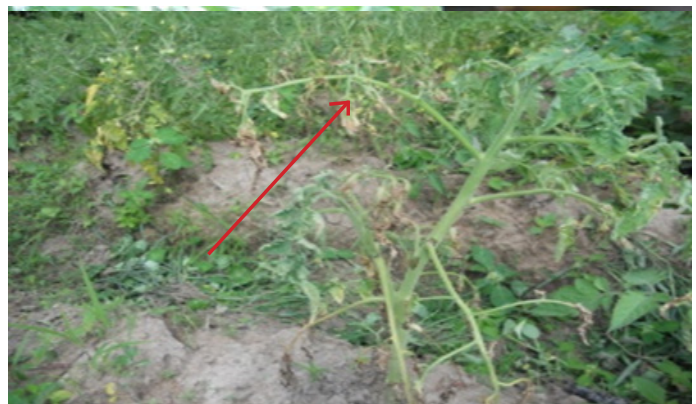

Fig. 5: Fusarium wilt of tomato (Symptoms arrowed)

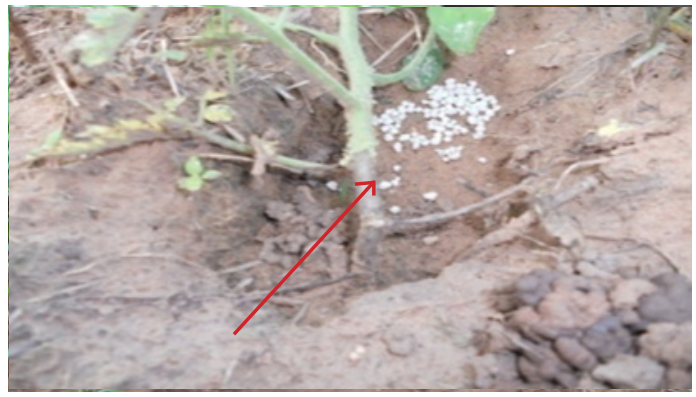

Fig. 6: Crown rot of tomato (Symptoms arrowed) 


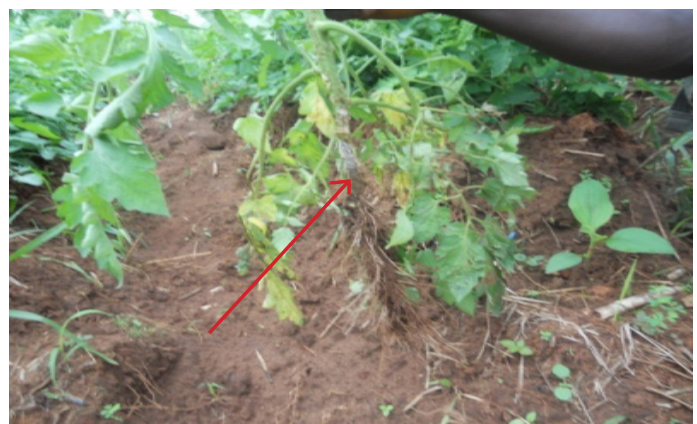

Fig. 7: Sclerotium rot of tomato (Symptoms arrowed)

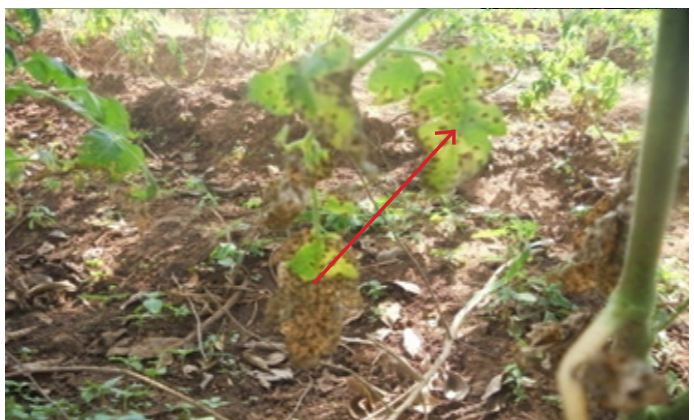

Fig. 8: Septoria leaf spot of tomato (Symptoms arrowed)

Respectively, the pathogens isolated from these tomato diseased plants were Alternaria solani (Ellis and Martin) Jones and Grout (Fig. 9), Fusarium oxysporum $f$. sp. lycopersici (Saccardo) Snyder and Hansen (Fig. 10), Fusarium sp. (Fig. 11) and Sclerotium rolfsii Sacc (Fig. 12).
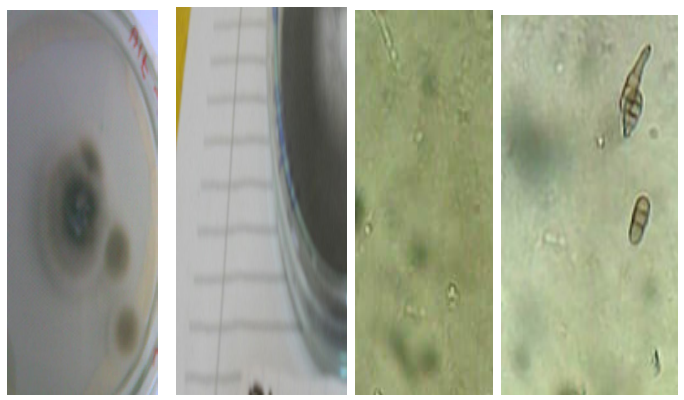

Fig. 9: Culture plate and conidia of Alternaria solani isolated from tomato plants showing symptoms of early blight disease
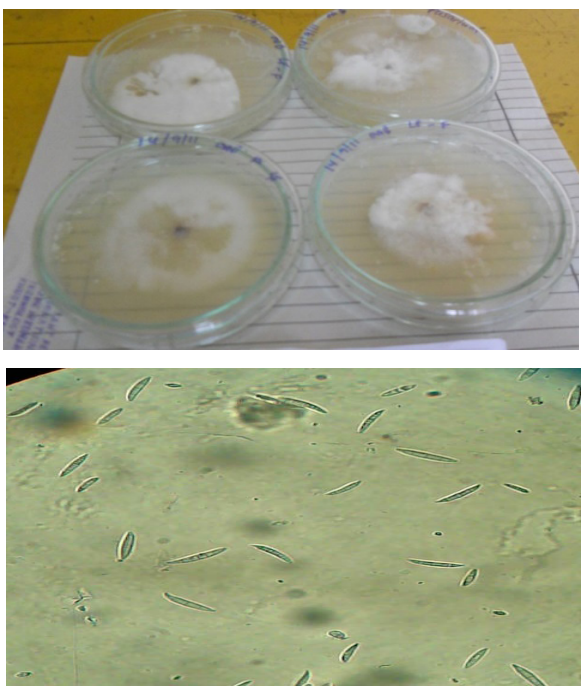

Fig. 10: Culture plates and conidia of Fusarium oxysporum isolated from tomato plants showing symptoms of Fusarium wilt disease
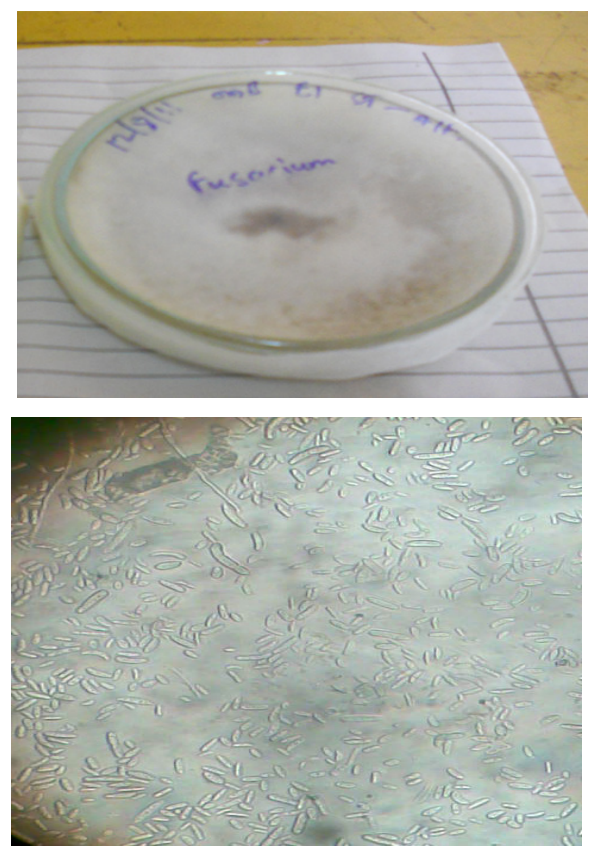

Fig. 11: Culture plate and conidia of Fusarium sp. isolated from tomato plants showing symptoms of crown rot disease 

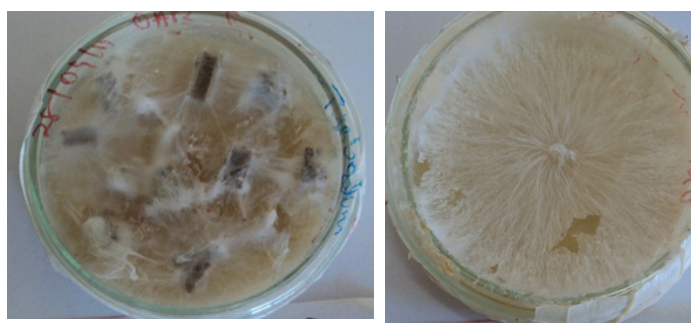

Fig. 12: Culture plates of Sclerotium rolfsii isolated from tomato plants showing symptoms of Sclerotium rot

Early blight was found in all the districts with the highest incidence of $63.9 \%$ occurring in Asante Akim North, followed by $43.5 \%$ in Offinso North District (Table 1). Septoria leaf spot was also found in all the districts with Offinso North District recording the highest incidence of $34.0 \%$ and Asante Akim North District recording the lowest incidence of $19.1 \%$. With regards to Fusarium wilt disease, the highest incidence of $45.2 \%$ occurred in Asante Akim North District (Table 1). The incidence of crown rot disease was 37.5\% in Asante Akim North District, the highest recorded in the three studied districts (Table 1). Sclerotium rot disease was only found in Offinso North and Techiman North Districts with Offinso North recording the highest incidence of $36.8 \%$ (Table 1).

TABLE 1

Incidence of major fungal diseases of tomato in the studied districts

\begin{tabular}{llllll}
\hline \multirow{2}{*}{ District } & \multicolumn{5}{c}{ Mean \% disease incidence /District } \\
\cline { 2 - 5 } & Early blight & Septoria leaf spot & Fusarium wilt & Crown rot & Sclerotium rot \\
\hline Asante Akim North & 63.9 & 19.1 & 45.2 & 37.5 & 0.0 \\
& $(0-90)$ & $(0-82)$ & $(0-83)$ & $(0-73)$ & $(0.0)$ \\
& & & & \\
Offinso North & 43.5 & 34.0 & 41.6 & 32.9 & 36.8 \\
& $(0-73)$ & $(0-80)$ & $(0-83)$ & $(0-77)$ & $(0-80)$ \\
Techiman North & 38.2 & 21.9 & & & 14.3 \\
& $(0-63)$ & $(0-67)$ & $(0-70)$ & $(0-60)$ & $(0-60)$ \\
\hline
\end{tabular}

Values in brackets are \% range of incidence of fungal diseases per district

The average severities of all the fungal diseases of tomato identified in the three districts were low. A severity of 2.0 was scored for early blight and Fusarium wilt diseases in Asante Akim North and Fusarium wilt and Sclerotium rot diseases in Offinso North District (Table 2). 
TABLE 2

Severity of fungal diseases of tomato in the studied districts

\begin{tabular}{|c|c|c|c|c|c|}
\hline \multirow[b]{2}{*}{ District } & \multicolumn{5}{|c|}{ Mean severity score (scale 1-5)* of fungal diseases / District } \\
\hline & Early blight & $\begin{array}{c}\text { Septoria leaf } \\
\text { spot }\end{array}$ & Fusarium wilt & Crown rot & Sclerotium rot \\
\hline Asante Akim North & 2.0 & 0.6 & 2.0 & 1.3 & 0.0 \\
\hline Offinso North & 1.5 & 1.1 & 2.0 & 1.1 & 2.0 \\
\hline Techiman North & 1.3 & 0.7 & 0.8 & 0.5 & 0.7 \\
\hline $\begin{aligned} & * \text { Scores represen } \\
1 \rightarrow & \text { No disease sympt } \\
2 \rightarrow & \text { Disease sympton } \\
3 \rightarrow & \text { Disease symptom } \\
4 \rightarrow & \text { Disease symptom } \\
5 \rightarrow & \text { Disease symptom }\end{aligned}$ & $\begin{array}{l}\text { ng means of se } \\
\text { ms } \\
\text { to cover } 5-25 \\
\text { to cover } 25-50 \\
\text { to cover } 50-7 \\
\text { expression on }\end{array}$ & $\begin{array}{l}\text { rity measured } \\
\text { of the total lea } \\
\text { of the total lea } \\
\text { of the total led } \\
\text { ind tissues to }\end{array}$ & $\begin{array}{l}1-5 \text { scale are de } \\
\text { ves) area } \\
\text { (ves) area } \\
\text { (ves) area } \\
\text { over } 75-100 \% \text { of }\end{array}$ & ed below: & \\
\hline
\end{tabular}

Tomato farmers' knowledge and perception of fungal diseases identified

The results showed that majority (76-99\%) of the total (90) tomato farmers knew the infections as diseases (Fig. 13) and reported that these diseases (Fig. 4-7) occurred at all stages of plant growth. They perceived the causes of these infections to be the soil and low temperature conditions. Most of the respondent farmers, about $97 \%$ perceived early blight damage as leaf yellowing of seedlings, yellowish spots and falling of leaves at the fruiting stage (Fig. 13). For severe infection, they reported that early blight causes yellowing of leaves to death of plants, formation of small fruits and fruit rot at the advanced stage. Also, 80 to $99 \%$ of farmers (Fig. 13) reported damage caused by Fusarium wilt as wilting and dying of tomato crops in the greenish state as early as three weeks after transplanting (Fig. 13). They also reported that crown rot produces basal stem canker on tomato plants and seedlings at the nursery. According to 80 $\%$ and $99 \%$ of respondent farmers, crown rot and fusarium wilt diseases respectively could cause wilting of tomato plant population at two to three weeks when the incidence of the two diseases are high. Plants that are able to tolerate the diseases produce small, few and sometimes rotten fruits when the infection occurs at the fruiting stage.

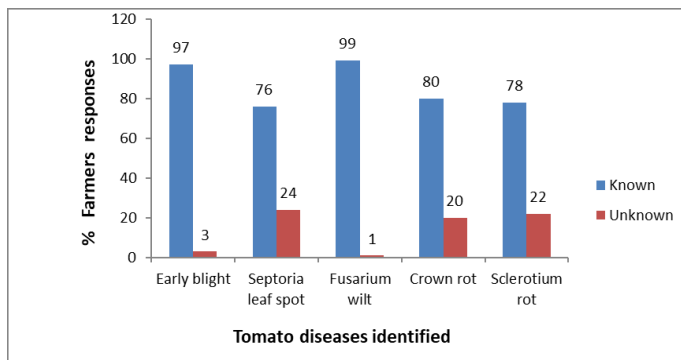

Fig. 13: Farmers' knowledge on fungal diseases of tomato identified

Tomato farmers' control measures against the fungal diseases identified

The results showed that apart from Sclerotium rot, the majority (72-98\%) of the farmers implemented a control measure (Fig. 14). Application of fungicides, according to the farmers, was the only strategy employed for 
the management of diseases. The commonly used fungicides included Dithane M-45 (Mancozeb); Topsin (Thiophanate-methyl); Kocide (Copper Hydroxide); Ridomil Plus (Mefenoxam); Funguran (Copper Hydroxide); and Champion (Copper Hydroxide). However, $52 \%$ of farmers do not implement control measures to Sclerotium rot (Fig. 14). Also, 48 to $98 \%$ of farmers who implemented control measures (Fig. 14) reported that they control these infections when they notice symptom expression on the field and also at two weeks after transplanting with the fungicides but these fungicides were not effective in controlling the diseases, especially fusarium wilt, crown rot and sclerotium rot. According to $83 \%$ of the respondent farmers who implemented control to crown rot also stated the application of N.P.K $15: 15: 15$ as a control measure to the crown rot disease.

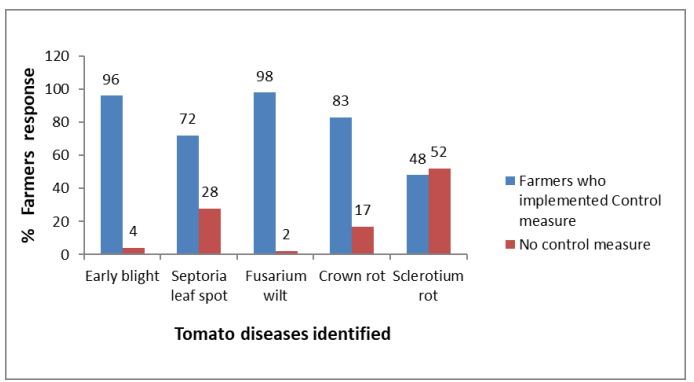

Fig. 14: Farmers' response to control measures on fungal diseases of tomato identified

Tomato farmers' sources of tomato seedlings Most $(79 \%)$ of the tomato farmers raised their seedlings on prepared beds on their fields meant for the seasonal tomato production and responded to farmer saved seeds as their source, while $10 \%$ of farmers patronized seedlings raised by their friends far away from their cultivated fields (Fig. 15). The remaining 11\% of the farmers obtained their seedlings from their own and their friends' nurseries (Fig. 15).

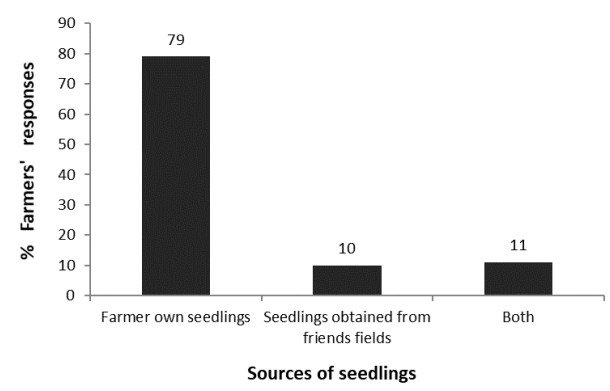

Fig. 15: Farmers' sources of tomato seedlings

Effect of fungal diseases on yield of tomato

All the tomato farmers $(100 \%)$ reported the diseases identified in their fields as major constraints in tomato production and cause yield loss (Table 3 ).

TABLE 3

Cost of tomato production and yield attained per 0.40 ha with disease and no disease effect in the studied districts

\begin{tabular}{lll}
\hline Variable & $\begin{array}{c}\text { Attainable } \\
\text { yield/crate }\end{array}$ & $\begin{array}{l}\% \text { Tomato } \\
\text { farmers }\end{array}$ \\
\hline
\end{tabular}

\section{A. Famers' cost of production GHe}

\begin{tabular}{lll}
$\begin{array}{l}400-500 \text { excluding farm- } \\
\text { ers effort }\end{array}$ & $100-135$ & 100 \\
$800-1000$ including & $100-135$ & 100 \\
farmers effort & & \\
B. Disease effect & & \\
$\begin{array}{l}\text { Incidence of disease } \\
\text { Absence of disease }\end{array}$ & $1-20$ & 100 \\
\hline
\end{tabular}

\section{Discussion}

Incidence and severity of fungal diseases of tomato in the studied districts

Early blight, Septoria leaf spot, Fusarium wilt, Crown rot and Sclerotium rot were the major fungal diseases identified in the study. These 
diseases had also been previously reported on tomato plants (Offei et al., 2008; Shankara et al., 2005; Agrios, 2005; MoFA, 1995; Clerk, 1974). The percentage mean incidence of diseases recorded for the districts was low with the exception of early blight ( $63.9 \%$ incidence) at Asante Akim North District. However, the percentage range of incidence of each disease identified per District (Table 1) was as high as $0-90 \%$ for early blight at Asante Akim North and as low as $0-60 \%$ for crown rot and sclerotium rot at Techiman North district. In disease situation, incidence at this range is capable to cause crop losses at all stages of plant growth to farmers. This is in line with the reports by Manners (1992) and Nash and Gardner (1988) that disease incidence at any percentage level can cause yield losses if not well managed.

According to Agrios (2005), for many diseases in which plants are counted as diseased, whether they are exhibiting a single lesion or hundreds of lesions, disease incidence and severity reduce yields and therefore cause losses. From the study, the mean fungal disease severities recorded in the three districts were low and could be attributed to the extensive application of fungicides. It was observed from the survey that the tomato plants affected by these diseases produced very small and few fruits. Mark and Brooke (2006) in their studies on tomato diseases and disorders reported that fusarium wilt-affected plants die and those that survive produce very small and few fruits.

The mean severity of 2.0, the highest score of early blight and fusarium wilt was recorded at Asante Akim North. The same mean severity score (2.0) was also recorded by fusarium wilt and sclerotium rot at Offinso North District. Since Offinso North District falls in the moist semi-deciduous forest zone and Asante Akim-
North District experiences semi equatorial type of climate with areas of forest-savannah transition, favourable conditions such as low temperature, high rainfall and high relative humidity pertaining in these zones could also enhance the development of these diseases to cause crop losses. The pathogens of early blight, fusarium wilt, and sclerotium rot of tomato exist in certain seasons of high rainfall, low temperature, and warm-humid conditions which become very difficult to control when they infest the soil as reported by Agrios (2005). This could account for the high application of chemical fungicides by $72-98 \%$ of the respondent farmers in the studied areas. Early blight of tomato caused by Alternaria solani is one of themost common and destructive diseases of tomato in areas of heavy dew, high rainfall and relative humidity (Norman, 1992). The control of tomato early blight disease has been almost exclusively based on the application of chemical fungicides. Though several effective fungicides have been recommended for use against this pathogen, they are not considered to be long-term solutions due to concerns of expense and exposure risks (Norman, 1992). The use of clean seeds saved from disease-free plants, practising three-year crop rotation with non-susceptible crops and the use of resistant or tolerant varieties are possible control measures (Norman, 1992).

According to Bachi and Seebold, (2008) Southern blight also known as Sclerotium rot caused by the fungus Sclerotium rolfsii Sacc. affects a wide variety of crops, including tomato and it grows well in areas of heavy dew, warm and humid climates worldwide. With regards to the incidence of these fungal diseases of tomato, observations in the fields and discussion with farmers indicated that very high incidence and severity of these infections cause severe losses 
in tomato production during the peak of high rainfall in the studied areas. The study showed that early blight, septoria leaf spot, fusarium wilt and crown rot were the most frequently occurring diseases in all the districts. This is in line with Norman (1992), Robinson and Kolavalli (2010) and Clottey et al. (2009) who identified early blight as prevalent foliar seedborne disease of tomatoes in Ghana, especially in the warm and humid environments of the Ashanti region.

Farmers' knowledge and control practices on tomato fungal diseases in the studied districts The results from the survey indicated that a high percentage of farmers had perceived knowledge of the fungal diseases of tomatoes because of losses that these diseases cause. Even though they had perceived knowledge and knew of these diseases, their knowledge of control practices was poor. At least $96 \%$ of the farmers controlled diseases using chemicals, but indications from the study showed that some of the farmers suffered severe yield losses despite the over dependence on chemicals. According to Wolff (1999), tomato farmers spent more money on chemicals to control diseases. Situations that would not demand chemical application were even given chemical treatment. The extensive application of these pesticides may contribute to chemical abuse on vegetables in the country. This situation has previously been reported by Robinson and Kolavalli (2010) and Clottey et al. (2009) in their studies of tomato production constraints in Ghana. Education of farmers on the application of appropriate disease control measures to these fungal diseases of tomatoes is critical.

It was recorded from the survey that majority of the farmers raised their own seedlings and utilized farmer-saved tomato seeds as their source. Their general reason was that it was easily affordable, resistant to diseases and pests, and adaptable to their climatic conditions. Some of the farmers patronized seedlings raised by their friends, thereby facilitating the movement of pathogens from one field to another. This implies that farmers contributed to the spread and buildup of diseases and seed-borne pathogens on their farms through seed-recycling. These agree with Agrios (2005), Manners (1992) and Park (1990) that, the use of seed, nursery stock, and other propagative material that carry various pathogens increase the amount of initial inoculum within the crop and favours the development of epidemics greatly.

The ineffectiveness of the available fungicides to control these fungal diseases reported by some farmers who control diseases could be attributed to the wrong time of application as 38 to $98 \%$ of farmers who implemented control measures reported that they control these infections when they notice symptom expression on field and also at two weeks after transplanting. This is in line with Norman (1992), Bachi and Seebold (2008) that for some of the infections that are seed and soil-borne, control measures must be implemented on seeds and at seedling and soil bed preparation time before transplanting. According to Norman (1992), farmers implement control measures to diseases at the wrong time. This indicates that the fungal pathogens could start the development of the infection (latent infection) and to the point of economic damage as reported by (Shankara $e t$ al., 2005) prior to the farmers' control measure. According to Agrios (2005) and Norman (1992), the pathogens of Alternaria solani and Fusarium oxysporum $f$. sp. lycopersici that causes early blight and fusarium wilt 
respectively in tomato are both seed and soil borne whereas the pathogen of sclerotium rot is soil-borne. This implies that farmers in these tomato growing zones must be educated on how to manage these tomato fungal infections right from the seeds and nursery level with emphasis on the mode and dosage of fungicides application for effective control.

According to the farmers, they spent GH 4 400-500, excluding the cost of their personal effort, and $\mathrm{GH} \phi 800-1000$ including the cost of their personal effort, on 0.40 ha of tomato production. This indicates that tomato production is capital intensive. Also, under good farming management practices and without disease incidence, farmers obtained 100 - 135 crates of tomatoes per 0.40 ha (yield of tomato is on 0.40 ha because most of the farms surveyed were 0.40 ha in size and data obtained from farmers on yield were with respect to 0.4 ha). However, if no disease control measure is applied, the incidence of diseases reduced yield to 1-20 crates per 0.40 ha of tomato farm depending on the type of disease. This also confirmed the report of GSSP (2010), IFPRI-PBS (2006) and Sinnadurai (1992) that diseases reduce the yield of tomatoes and affect farmers' livelihoods in the major production areas of Ghana.

\section{Conclusion}

The result of the study revealed that Early blight, Fusarium wilt, Sclerotium rot, Septoria leaf spot and Crown rot were the major fungal diseases of tomato found to cause massive yield loss and threaten tomato cultivation in Techiman North, Asante Akim North and Offinso North Districts within the forest and forest-savannah agro-ecological zones of Ghana. Early blight, Fusarium wilt and Sclerotium rot were the highest scored fungal diseases of tomato identified in the studied areas compared to the other diseases with regards to severity. The percentage mean incidence of diseases recorded for the districts was low with the exception of early blight (63.9\% incidence) at Asante Akim North District. Though the mean fungal disease severities in the three districts were also low, the highest score of early blight and fusarium wilt; and fusarium wilt and sclerotium rot were recorded in the Asante Akim North and Offinso North Districts respectively. Farmers had perceived knowledge of the tomato diseases because of losses that these diseases caused. Despite their perceived knowledge of the diseases due to losses, their knowledge on control practices was poor.

\section{Recommendations}

- To manage fungal diseases of tomatoes, practices such as rotation, sanitation, appropriate timing of fungicide application, seed treatment and nursery bed treatment are recommended

- Sensitization programmes should be conducted with all stakeholders in the tomato industry, especially tomato farmers and the Agric Extension Agents on the awareness and appropriate management strategies for tomato fungal diseases.

- Lastly, further studies should be conducted in both the major and minor seasons using integrated pest and disease management approach in the study districts to provide more information for better management of fungal diseases of tomatoes in Ghana.

\section{REFERENCES}

Agrios, G.N. (2005) Plant Pathology, $5^{\text {th }}$ Edition, Elsevier Academic Press Inc. New York. p. 922.

Alam, T., Tanweer, G. \& Goyal, G.K. (2007) Stewart Postharvest Review, Packaging and storage of tomato puree and paste. Research article, 
Volume 3, Number 5: 1-8 October 2007 released, Publisher: Stewart postharvest solutions. DOI: 10.2212/spr.2007.5.1

Asselt, V.J., Masias, I. \& Kolavalli, S. (2018) Competitiveness of the Ghanaian vegetable sector. International Food Policy Research Institute, Working paper 47, $1-28$.

Bachi, P. \& Seebold, K. (2008) PPFS-VG-03, Plant pathology fact sheet, University of Kentucky Cooperative Extension Service, College of Agriculture, revised January 2008: 1-2. Online Date accessed 26/06/12.

Barnett, H. L. \& Hunter, B. (1972) Illustrated Genera of Imperfect Fungi, third edition.Burgess publishing incorporated, p. 241.

Chupp, C. \& Sherf, A. F. (1960) Vegetable Diseases and Their Control, Ronald Press Company, New York, $534-566$.

Clerk, G. C. (1974) Crops and their diseases in Ghana, Ghana Publishing Corporation, Tema. OCLC No. 2307075. p. 144.

Clottey, V.A., Karbo, N. \& Gyasi, K. O. (2009) The tomato industry in Northern Ghana: Production constraints and strategies to improve competitiveness. A Report Article Published by African Journal of Food, Agriculture, Nutrition and Development 9 (6). ISSN 164 - 5374,

Coolong, T. \& Boyhan, E. G. (2017) Commercial tomato production handbook. Bulletin 1312, University of Georgia Agric Extension.

Council for Scientific and Industrial ResearchCrop Research Institute (2011) Annual report, $61-70$.

Duodu, F. (2014) Tomato disease attacks farms in Agotime-Ziope. Business and Finance, Business Guide: https://www.modernghana. com/news/555472.[Accessed: 14-06-2021].
Ghanaweb.com (2020) Ghana: Tomato farmers in Tuobodom deplore Burkina Faso imports. [Accessed: 14-06-2021].

Ghana Strategy Support Programme (GSSP) April 2010 Report. The case of tomato in Ghana: Productivity. Working Paper \# 19.

Gonzalez, S.Y., Dijkxhoorn, Y., Koomen, I., Maden, V.D.E., Herms, S., Joosten, F. \& Mensah, A.S. (2016) Ghana Vegetable Sector Report, Wageningen, UR, $1-84$.

Horna, D., Smale, M., Al-Hassan, R., Falck, Z. \& Timpo, S.E. (2008) Insecticide use on vegetables in Ghana. Would GM seed benefit farmers? IFPRI Discussion Paper, 00785.

Horna, D., Zabel, P. \& Lindout, P. (2006) Assessing the potential economic impact of genetically modified crops in Ghana: Tomato, garden egg, cabbage and cassava. Program for Biosafety Systems report, p. 42.

International Food Policy Research Institute (IFPRI) (October 2006): Programme for Biosafety Systems Report (PBS), www.ifpri. org/themes/gssp/gssp.htm

Jones J. B., Jones J. P., Stall. R. E. \& Zitter, T. A. (1991). Compendium of Tomato Diseases. Minnesota, American Phytopathological Society. p. 73.

Kari, P., Froikin-Gordon, J. S., Issoufou, K. A., Levasseur, V., Aissatou, A. A., Mensah, A., Offei, B., Boukary, H., Assogba-Komlan, F., Abdou, A. M., Moussa, N., Lenli, C.O., Ouedraogo, L., Kon, T., Rojas, M. R., Kadiatou, T. G., Shotkoski, F., Robert, L. G. \& Molly, M. J. (2017) Connecting smallholder tomato producers to improved seed in West Africa. Agriculture and Food Security 6 (42), 1 - 14.

Manners, J. G. (1992) Principles of Plant Pathology $2^{\text {nd }}$ Ed. Cambridge University press, 187 260. 
Mark, L. G. \& Brooke, A. E. (2006) Tomato diseases and disorders, online, Iowa State University, Department of Plant Pathology, PM 1266. Revised 2006:1-12, Date accessed 26/06/12.

Mathur, S. B. \& Kongsdal, O. (2003) Common Laboratory Seed Health Testing Methods for Detecting Fungi. Kandrup Bogtrykkeri, Arhusgade 88, DK - 2100 Copenhagen, Denmark, p. 436.

MoFA (2002) Food and Agriculture Sector Development Policy (FASDEP), Delonon Publishers. Accra, 52 - 57.

MoFA (1995) Technical Report on Diseases and Pest Survey and Control Exercise. Central Region of Ghana.Ministry of Food and Agriculture of Ghana.

Nash A.F. \& Gardner, R.G. (1988) Tomato early blight resistance in a breeding line derived from Lycopersicon hirsutum PI 126445. Plant Disease 72, 206 - 209.

Norman, J.C. (1992) Tropical Vegetable Crops. Arthur. H. Stockwell Ltd. Elms court, Devon, London, UK. ISBN 0-7223 2595-9, 52 - 76.

Offei, S.K., Cornelius, E.W. \& Sakyi-Dawson, O. (2008) Crops diseases in Ghana and their management; General books ISBN-10 9988600-27-51, Smartline publishers limited, Accra, p. 104.

Park, R.F. (1990) The role of temperature and rainfall in the epidemiology of Puccinia striiformis.f.sp.tritici in the summer rainfall area of eastern Australia. Plant Pathology Journal 39, 416- 439.
Robinson, J.Z.E. \& Kolavalli, L.S. (2010) The Case of Tomato in Ghana: Processing. Working Paper \# 21. Development and Strategy Governance Division, IFPRI, Accra, Ghana: Ghana Strategy Support Program (GSSP), 1 -10 .

Shankara N., Joep van Lidt de Jeude, Marja de Goffau, Martin Hilmi, Barbara \& Van Dam:Agrodok 17 (2005) (C) Agromisa Foundation and CTA, Wageningen, 2005. Digigrafi, Wageningen, Netherlands ISBN Agromisa: 90-8573-039-2, ISBN CTA: 929081-299-0, 6 - 54. (www.prota.org) online date accessed 26/06/2012

Sinnadurai, S. (1992) Vegetable production in Ghana, Asempa Publishers, Accra, $155-158$.

Tambo, J.A. \& Gbemu, T. (2010) resource-use efficiency in tomato production in the Dangme West District, Ghana. Conference on International Research on Food Security, Natural Resource Management and Rural Development. Tropentag, ETH Zurich, Swzld.

Villareal, R. L. (1980) Tomato in the tropics. IADS Development Oriented Literature Series. p. 174.

Wener, J. N. (2000) Guide to tomato production in home gardens, available www.agrisupportonline. com Date accessed 23/10/11.

Wolff, H. (1999) Economics of Tomato Production with special Reference to Aspects of Plant Protection: A case study of two tomato production systems in Brong-Ahafo Region, Ghana. Ghanaian-German Project for Integrated Crop Protection, GTZ Eschborn, p. 131. 